\title{
Protein content of leaf-cutting ant queens before the nuptial flight and during the post-claustral phase
}

\author{
Edypo Jacob Silva ${ }^{1}$, Roberto da Silva Camargo ${ }^{1,2}$, Luiz Carlos Forti ${ }^{1} \&$ Raphael Vacchi Travaglini ${ }^{1}$
}

\author{
'Laboratório de Insetos Sociais-Praga, Departamento de Produção Vegetal, Faculdade de Ciências Agronômicas/UNESP, Caixa Postal 237, \\ 18603-970 Botucatu-SP, Brasil. \\ ${ }^{2}$ Corresponding author: camargobotucatu@yahoo.com.br
}

\begin{abstract}
Protein content of leaf-cutting ant queens before the nuptial flight and during the post-claustral phase. This study evaluated the crude protein content of queens of Atta sexdens before the nuptial flight and after the claustral phase in laboratory and field colonies. The hypothesis was that protein is used for survival of the queen and for early colony growth during the claustral phase. Additionally, the nest morphology, live biomass and adult population of field colonies were evaluated. Crude protein was determined by digestion of the organic material with sulfuric acid at high temperatures. The mean crude protein content was $123.23 \pm 11.20 \mathrm{mg}$ for females before the nuptial flight and $70.44 \pm 12.21 \mathrm{mg}$ for laboratory-reared queens after the claustral phase. The post-claustral crude protein content of field-collected queen was $55.90 \pm 9.18 \mathrm{mg}$. With respect to the loss of crude protein as a function of duration of the claustral phase, laboratory-reared queens lost $52.79 \mathrm{mg}$ and field-collected queens lost $67.33 \mathrm{mg}$ compared to females before the nuptial flight. A positive linear correlation was observed between the weight of field-collected queens $(256.4 \pm 36.3 \mathrm{mg})$ and colony biomass $(13.02 \pm 9.12 \mathrm{~g})$, but there was no correlation between biomass and nest depth $(13.11 \pm 3.82 \mathrm{~cm})$. As expected, the present results support the hypothesis that protein is used for survival of the queen and for early colony growth, as demonstrated by the reduction in crude protein content as a function of duration of the claustral phase. To our knowledge, this is the first study to provide data of the dynamics of protein reserves in leaf-cutting ant queens during the claustral phase.
\end{abstract}

KEYWORDS. Claustral phase; Insecta; leaf-cutting ants; nest; protein content.

Nest founding is claustral in Atta leaf-cutting ants, except for A. cephalotes which exhibits semi-claustral founding (Weber 1972). Ant queens rely on their body reserves to maintain their activities until the ûrst workers emerge and start foraging (Hölldobler \& Wilson 1990). Claustral queens have a larger body size due to the storage of lipids, carbohydrates and proteins required for the activities during the claustral phase (Boomsma \& Isaaks 1985; Brown \& Bonhoeffer 2003; Keller \& Passera 1989; Seal 2009; Seal $\&$ Tschinkel 2007). Nuptial flight, nest digging and the claustral phase demand great energy and time investments by the queen. In this respect, little is known about how queens spend these energy resources for the success of nest founding.

The nuptial flight is a high energy-consuming activity, as demonstrated by Jutsum \& Quinlan (1978) and Passera et al. (1989) for winged individuals of Atta sexdens and Formica lugubris, respectively. The authors observed that carbohydrates correspond to $21 \%$ of the dry weight of winged ants, which are fully consumed after the nuptial flight. After the nuptial flight, Atta sexdens queens land on the ground, remove their wings, and initiate colony founding.

These studies indicate that the first energy resource to be depleted during the nuptial flight is the carbohydrate reserve. Lipids and proteins are degraded more slowly than carbohydrates, saving these reserves for activities that are necessary after the nuptial flight. Before leaving the nest of origin, males and females are probably well nourished and ready to mate. Approximately $40 \%$ of the body mass of Atta sexdens queens is composed of lipids (Seal 2009; Fujihara et al. 2012) and the queens possess sufficient energy reserves to maintain a high rate of offspring production for several weeks (Camargo et al. 2011). In fact, queens lose about $40 \%$ of their body mass after 60 days (Della Lucia et al. 1995), reaching a minimum body mass before the first workers start foraging. Once foraging has begun, the queen recovers her body mass as a result of feeding inside the colony (Della Lucia et al. 1990). The queens subsequently recover their weight and lipid reserves, storing up to $6.4 \%$ of fat within a period of 12 months (Camargo \& Forti 2013). Therefore, offspring production depends on body reserves (lipids from the fat body and wing muscle protein), since the queen does not feed during the period of colony founding (Fowler et al. 1986). However, it remains unknown how much protein is metabolized during the claustral phase.

In view of the above considerations, we hypothesized that protein is used for the survival of the queen and for early colony growth during the claustral phase. We therefore determined the crude protein content of queens before the nuptial flight and after the claustral phase in laboratory and field colonies. Additionally, the nest morphology, live biomass and adult population of field colonies were evaluated. 


\section{MATERIAL AND METHODS}

\section{Collection of Atta sexdens females before the nuptial} flight and after the claustral phase. Females were collected from a nest of $A$. sexdens in loose soil before the nuptial flight. The insects $(\mathrm{N}=40)$ were taken to the laboratory, immediately killed, and analyzed for protein content. Mated females (post-nuptial flight) were collected after they had lost their wings and started colony founding $(\mathrm{N}=$ 20). After collection, the insects were immediately stored in plastic containers $(11 \mathrm{~cm}$ in diameter, $8 \mathrm{~cm}$ high $)$ filled with $1 \mathrm{~cm}$ of plaster at the bottom to keep the air moist. Queens were transported to the Laboratory of Social Insects (Laboratório de Insetos Sociais-Praga), FCA/UNESP, Botucatu, SP, Brazil.

Four months after the nuptial flight, initial nests were excavated $(\mathrm{N}=22)$ in an area planted with Eucalyptus spp. These nests were collected and nest morphology parameters were obtained: tunnel length and chamber dimensions (length, width and height). In the laboratory, the live biomass (fungus garden, eggs, larvae, pupae, and adults) and size of the adult population were determined by direct weighing in a semi-analytical balance.

Determination of crude protein. Queens were weighed and dried in a 300-ml digestion tube. A standard measure of catalyst mixture and $3 \mathrm{ml}$ concentrated sulfuric acid were added to the tube. The catalyst mixture is $\mathrm{K}_{2} \mathrm{SO}_{4}+\mathrm{CuSO}_{4}$; 10:1. The mixture was incubated in a digestion block whose temperature was gradually increased to $400^{\circ} \mathrm{C}$. The resulting extract with a clear green color was cooled and titrated. Next, a standard volume of $\mathrm{NaOH}(15 \mathrm{ml})$ was added and heating was initiated. The tube was then transferred to an Erlenmeyer flask containing $10 \mathrm{ml}$ boric acid $1 \%$, with indicators at the exit of the distiller which was immersed in boric acid. Once a volume of $50 \mathrm{ml}$ of the distillate was obtained, the heating was removed. The volume of the Erlenmeyer flask was titrated with $0.05 \mathrm{~N}$ sulfuric acid until the color changed and the volume of acid used was recorded. Crude protein was calculated using the following formula:\% nitrogen $=(14 * 0.05 * 100) / 100) *\left(\right.$ vol $\mathrm{H}_{2} \mathrm{SO}_{4}-$ vol blank $)$, where $14=$ nitrogen equivalent; $0.05=$ normality of sulfuric acid; $100=100 \%$ (to express the result in percentage); $100=$ mass used (in $\mathrm{mg}$ ); vol $\mathrm{H}_{2} \mathrm{SO}_{4}=$ volume of acid used until the point of color change; vol blank = volume of acid used until the point of color change of the blank. The percentage of crude protein is given by $\%$ nitrogen multiplied by 6.25 . The method of crude protein determination is Kjeldahl analysis (Kjeldahl 1883).

Statistical analysis. The protein content of laboratoryreared and field-collected queens before the nuptial flight and after the claustral phase was compared by the Student $t$-test. Additionally, Pearson's linear correlation test was applied to determine the relation between queen weight, biomass and nest depth. The BioStat 5.0 program was used for analysis and graphs.

\section{RESULTS}

The mean crude protein content was $123.23 \pm 11.20 \mathrm{mg}$ for females before the nuptial flight (dry weight: $239.55 \pm$ $36.0 \mathrm{mg}$ ) and $70.44 \pm 12.21$ for laboratory-reared queens after the claustral phase (dry weight: $95.94 \pm 20.3 \mathrm{mg}$ ), with detection of a significant difference $(t$-test, $\mathrm{t}=-10.0735$, d.f. $=$ $18, \mathrm{p}<0.0001$ ) (Fig. 1). A significant difference in crude protein content $(t$-test, $\mathrm{t}=-14.7019$, d.f. $=18, \mathrm{p}<0.0001)$ was also observed between females before the nuptial flight and field-collected queens after the claustral phase (dry weight: $76.70 \pm 11.5 \mathrm{mg}$; crude protein: $55.90 \pm 9.18 \mathrm{mg}$ ) (Fig. 1). However, no differences were found when laboratory-reared and field-collected queens after the claustral phase were compared $(t$-test, $\mathrm{t}=-3.0107$, d.f. $=18, \mathrm{p}=0.0075)$.

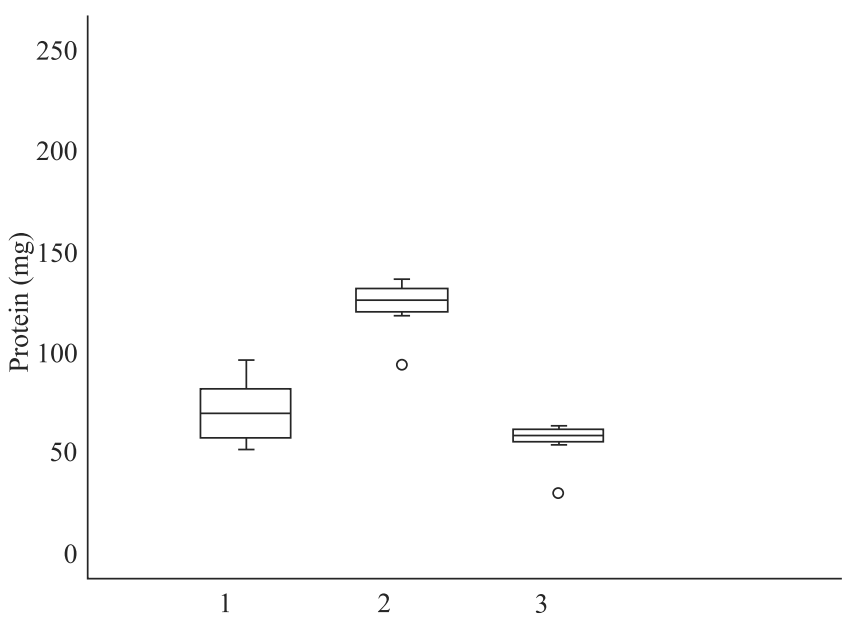

Fig. 1. Crude protein content (mg) of Atta sexdens queens: (1) laboratoryreared, post-claustral phase; (2) before the nuptial flight; (3) field-collected, post-claustral phase. Data are the mean, quartiles and range. Empty circles are outliers. For statistics, see text.

The percentage of crude protein in relation to total body mass was $74.4 \%$ for laboratory-reared queens and $59.1 \%$ for field-collected queens after the claustral phase compared to $51.4 \%$ for females before the nuptial flight. With respect to the loss of crude protein as a function of duration of the claustral phase, laboratory-reared queens lost $52.79 \mathrm{mg}$ and field-collected queens lost $67.33 \mathrm{mg}$ compared to females before the nuptial flight.

A significant positive correlation was observed between the weight of field-collected queens $(256.4 \pm 36.3 \mathrm{mg})$ and colony biomass (13.02 $\pm 9.12 \mathrm{~g})$ (Pearson's linear correlation, $\mathrm{r}=0.7951$, d.f. $=20, \mathrm{p}<0.0001$ ) (Fig. 2). However, there was no correlation between biomass and nest depth $(13.11 \pm 3.82 \mathrm{~cm})$ (Pearson's linear correlation, $r=-0.3438$, d.f. $=20, p=0.1171)$. The nests contained on average 650.5 \pm 447.9 workers and the chamber had the following dimensions: length of $8.14 \pm 2.29 \mathrm{~cm}$, width of $7.54 \pm 2.07 \mathrm{~cm}$, and height of $7.54 \pm 2.07 \mathrm{~cm}$. 


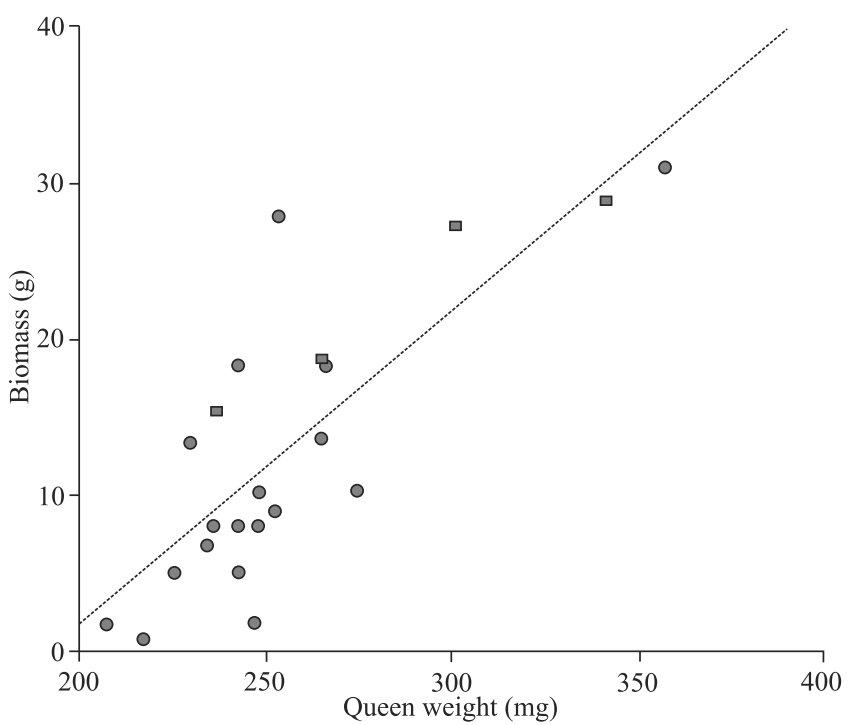

Fig. 2. Live biomass of colonies ( $\mathrm{g}$ ) and queen weight (mg) of Atta sexdens. Pearson's linear correlation between queen weight and biomass $(\mathrm{r}=0.7951$, d.f. $=20, \mathrm{p}<0.0001)$.

\section{DISCUSSION}

The present results support the hypothesis that protein is used for survival of the queen and for early colony growth, as demonstrated by the reduction in crude protein content as a function of duration of the claustral phase. Laboratoryreared queens lost $52.79 \mathrm{mg}$ and field-collected queens lost $67.33 \mathrm{mg}$ compared to females before the nuptial flight (Fig. 1). Energy regulation probably exists during this phase of reproduction of leaf-cutting ants. First, carbohydrates are used as energy source for the nuptial flight (Jutsum \& Quinlan 1978) and nest digging (Camargo et al. 2013a). Next, lipids are used for egg production (reproductive and trophic), taking care of the offspring and fungus garden, and self-grooming (Augustin 2011; Camargo et al. 2013b). Additionally, crude protein is mobilized for different purposes and its content declines over time as observed in the present study. Immediately after the nuptial flight, the queen lands on the ground and removes her wings. Thereafter, the wing musculature undergoes a process of reabsorption which starts on the first day after insemination. The highest rate of reabsorption is observed by day 45 (Cruz Landin \& Silva de Moraes 1979). The authors reported that reabsorption is related to the secretory activity of the corpora allata, in addition to the process of vitellogenesis.

According to Fowler et al. (1986), egg production by the queen during the 3 or 4 months of life of the colony is correlated with the activity cycle of the corpora allata. The latter are responsible for the synthesis of juvenile hormone which is involved in egg laying by founding queens, as demonstrated in females submitted to allatectomy (Barker 1978). Juvenile hormone acts on the fat body, inducing the synthesis of vitellogenin, a glycophosphoprotein containing lipids and carbohydrates, which will be deposited in the oocyte
(Chapman 1998). Offspring production therefore depends on body reserves (lipids from the fat body and wing muscle protein), and, probably explains the differences between crude protein content of females before the nuptial flight and fieldcollected queens after the claustral phase (Fig. 1).

The percentage of crude protein in relation to total body mass was $74.4 \%$ for laboratory-reared queens and $59.1 \%$ for field-collected queens after the claustral phase compared to $51.4 \%$ for females before the nuptial flight. A drastic change in body composition can be noted, i.e., large amounts of lipids and proteins are available at the beginning of nest founding, consequently showing a more equal distribution. The body lipid content of $A$. sexdens queens is known to be high during the early stage of colony founding, with $36.50 \pm 2.48 \%$ of body fat at the time of the nuptial flight which decreases to $9.17 \pm 5.21 \%$ after about 3 months (Camargo \& Forti 2013). Over time, lipids decrease at a higher proportion than proteins in relation to total body mass. Cruz-Landin \& Silva de Moraes (1979) suggested that the fat body is fully consumed until 60 days to be mobilized for vitellogenesis, a phase when the ovary shows highest growth, since Atta sexdens queens do not feed.

Furthermore, the weight of field-collected queens was positively correlated with colony biomass, i.e., heavier queens lay more eggs and consequently present a larger population. This positive correlation is reflected on the population, which achieved an average size of $650.5 \pm 447.9$ workers. Wide population variability is observed in 4-month-old colonies as demonstrated by Camargo et al. (2013b), with a strong influence of the environment on their natural habitat (Camargo et al. 2013b; Viera-Neto \& Vasconcelos 2010; Seal $\&$ Tschinkel 2008). Probably, this variability is due to the availability of palatable resources for foragers and a consequent increase in fungal biomass responsible for the increase in population size and queen weight (Camargo et al. 2013b).

Food quality is extremely important. As an example, Camargo et al. (2008) offered a single plant to initial Atta sexdens colonies for 2 months. The plant species offered included Acalypha spp., which promoted greater population growth, a higher queen weight, a higher egg laying rate, and a higher production rate of staphylae (swollen hyphae of the fungus garden which are the primary food source of the larvae) (Bass \& Cherrett 1996). This is another explanation for the large population variability seen in the present study (Fig. 2).

The chamber dimensions (length: $8.14 \pm 2.29 \mathrm{~cm}$, width: $7.54 \pm 2.07 \mathrm{~cm}$ and height: $7.54 \pm 2.07 \mathrm{~cm})$ were greater than those reported by Camargo \& Forti (2013) for the same species. This difference was due to the fact that the colonies studied here had a greater fungal biomass. It is known that the fungus garden serves as a three-dimensional template for the regulation of chamber size in leaf-cutting ants (Fröhle \& Roces 2009).

Another interesting result was the lack of a correlation between live biomass (13.02 $\pm 9.12 \mathrm{~g})$ and nest depth $(13.11 \pm$ $3.82 \mathrm{~cm}$ ), probably due to the ideal depth of the chamber. It is 
known that the control of nest depth has been evolutionary selected as a trade-off to maximize nest depth, to favor protection of the queen against unsuitable environmental variables, and to minimize energy expenditure during digging, which significantly affects survival (Camargo et al. 2011).

In conclusion, the determination of crude protein in Atta sexdens queens before the nuptial flight and after the claustral phase in laboratory and field colonies, as well as the analysis of nest morphology, live biomass and adult population, supports the hypothesis that protein is used for survival of the queen and for early colony growth during the claustral phase

\section{ACKNOWLEDGEMENTS}

We thank Coordenação de Aperfeiçoamento de Pessoal de Nivel Superior (CAPES) for the Postdoctoral fellowship granted to R.S. Camargo, and CNPq for the research productivity fellowship granted to L.C. Forti (grant 301718/2013-0).

\section{REFERENCES}

Bass, M. \& Cherrett, J.M. 1996. Leaf-cutting ants (Formicidae, Attini) prune their fungus to increase and direct its productivity. Functional Ecology 10: 55-61.

Barker, J.F. 1978. Neuroendocrine regulation of oocyte maturation in imported fire ant Solenopsis invicta. General and Comparative Endocrinology 35: 234-237.

Boomsma, J.J. \& Isaaks, J.A. 1985. Energy investment and respiration in queens and males of Lasius niger (Hymenoptera: Formicidae). Behavioral Ecology and Sociobiology 18: 19-27.

Brown, M.J.F. \& Bonhoeffer, S. 2003. On the evolution of claustral colony founding in ants. Evolutionary Ecology Research 5: 305-313.

Camargo, R.S.; Forti, L.C.; Lopes, J.F.S. \& Matos, C.A.O. 2008. Growth of population and fungus garden of Atta sexdens rubropilosa in response to foraged substrate. Sociobiology 52: 633-643.

Camargo, R.S., Forti, L.C., Fujihara, R.T. \& Roces, F. 2011. Digging effort by leaf-cutting ant queens (Atta sexdens rubropilosa) and its effects on survival and colony growth during the claustral phase. Insectes Sociaux 58:17-22.

Camargo, R.S. \& Forti, L.C. 2013. Queen lipid content and nest growth in the leaf cutting ant (Atta sexdens rubropilosa) (Hymenoptera: Formicidae). Journal of Natural History 47: 65-73.

Camargo, R.S., Lopes, J.F.S., Forti, L.C., Somera, A. \& Bacci Jr, M. 2013 a. Energy substrate used by leaf cutting ant workers during nest excavation. Revista Brasileira de Entomologia 57: 397-400.

Camargo, R.S., Fonseca, J.A., Lopes, J.F.S. \& Forti, L.C. 2013b. Influência do ambiente no desenvolvimento de colônias iniciais de formigas cortadeiras (Atta sexdens rubropilosa). Ciência Rural 43: 1375-1380.
Chapman, R.F. 1998. The Insects: Structure and Function. $4^{\text {th }}$ ed. Cambridge, Cambridge University Press, 788 p.

Cruz-Landin, C. \& Silva de Moraes, R.L.M. 1979. Flight muscle degeneration in Atta sexdens queens (Hym., Formicidae): Studies under electron microscope. Cytobios 24: 13-23.

Della Lucia, T.M.C., Moreira, D.D.O., Oliveira, M.A. \& Araujo, M.S. 1995. Perdas de peso de rainhas de Atta durante a fundação e o estabelecimento das colônias. Revista Brasileira de Biologia 55: 533-536.

Della Lucia, T.M.C., Vilela, E.F., Moreira, D.D.O., Bento, J.M.S. \& Dos Anjos, N. 1990. Egg-laying in Atta sexdens rubropilosa, under laboratory conditions, p. 173-179. In: Vander Meer, R.K., Jaffe, K. \& Cedeno, A. (eds.). Applied Myrmecology_A World Perspective. Boulder, Westview Press, 741 p.

Fröhle, K. \& Roces, F. 2009. Underground agriculture: the control of nest size in fungus-growing ants, p. 95-104. In: Theraulaz, G., Solé, R \& Kuntz, P. (eds.). From insect nest to human architecture. Venice, European Centre for Living Technology, 454 p.

Fowler, H.G., Pereira-da-Silva, V., Forti, L.C. \& Saes, N.B. 1986. Population dynamics of leaf-cutting ants: a brief review, p. 123-145. In: Lofgren, C.S. \& Vander Meer, R.K. (eds). Fire ants and leaf-cutting ants: Biology and management Westview Press, $435 \mathrm{p}$.

Fujihara, R.T., Camargo, R.S. \& Forti, L.C. 2012. Lipid and energy contents in the bodies of queens of Atta sexdens rubropilosa Forel (Hymenoptera, Formicidae): pre- and post-nuptial flight. Revista Brasileira de Entomologia 56: 73-75.

Hölldobler, B. \& Wilson, E.O. 1990. The Ants. Cambridge, Harvard University Press, $732 \mathrm{p}$.

Jutsum, A.R. \& Quinlan, R.J. 1978. Flight and substrate utilisation in laboratory-reared males of Atta sexdens. Journal Insect Physiology 24: 821-825.

Keller, L. \& Passera, L. 1989. Size and fat content of gynes in relation to the mode of colony founding in ants (Hymenoptera; Formicidae). Oecologia 80: 236-240.

Kjeldahl, J. 1883. Neue Methode zur Bestimmung des Stickstoffs in organischen Körpern. Zeitschrift für Analytische Chemie 22: 366-382.

Passera, L., Keller, L., Grimal, A., Chautems, D., Cherix, D., Fletcher, D.J.C., Fortelius, W., Rosengren, R. \& Vargo, E.L. 1989. Carbohydrates as energy source during the flight of sexuals of the ant Formica lugubris (Hymenoptera: Formicidae). Entomologia Generalis 15: 25-32.

Seal, J.N. 2009. Scaling of body weight and fat content in fungus gardening ant queens: does this explain why leaf-cutting ants found claustrally? Insectes Sociaux 56: 135-141.

Seal, J.N. \& Tschinkel, W.R. 2007. Energetics of newly-mated queens and colony founding in the fungus-gardening ants Cyphomyrmex rimosus and Trachymyrmex septentrionalis (Hymenoptera: Formicidae). Physiological Entomology 32: 8-15.

Vieira Neto, H.E. \& Vasconcelos, H.L. 2010. Developmental changes in factors limiting colony survival and growth of the leaf-cutters ants Atta laevigata. Ecography 33: 538-544.

Weber, N.A. 1972. Gardening Ants. The Attines. Memoirs of the American Philosophical Society 92. Philadelphia, American Philosophical Society, $146 \mathrm{p}$. 